\title{
Elbow septic arthritis associated with pediatric acute leukemia: a case report and literature review
}

\author{
Çocukluk çağı akut lösemisi ile ilişkili dirsek septik artriti: \\ Bir olgu sunumu ve literatür incelemesi
}

\author{
Takuya Uemura, MD., PhD., ${ }^{1}$ Hirohisa Yagi, MD., ${ }^{2}$ Mitsuhiro Okada, MD., PhD., Takuya Yokoi, MD., \\ Kosuke Shintani, MD., ${ }^{1}$ Hiroaki Nakamura, MD. PhD. ${ }^{1}$ \\ 1Department of Orthopaedic Surgery, Osaka City University Graduate School of Medicine, Osaka, Japan \\ ${ }^{2}$ Department of Orthopaedic Surgery, Seikeikai Hospital, Sakai, Japan
}

\begin{abstract}
Acute leukemia in children presents with various clinical manifestations that mimic orthopaedic conditions. The association of septic arthritis of the elbow with acute leukemia is very rare, and the correct diagnosis of acute leukemia is often established only after treatment of the septic arthritis. In this article, we present a three-year-old child patient with elbow septic arthritis related to acute leukemia, diagnosed promptly by bone marrow aspiration on the same day as emergency surgical debridement of the septic elbow joint due to the maintenance of a high index of suspicion, and treated with chemotherapy as soon as possible. The emergency physician and orthopaedist must recognize unusual patterns of presentation like this. Since delay in initiating treatment of septic arthritis may result in growth disturbance, elbow septic arthritis associated with pediatric acute leukemia must be treated promptly and appropriately. Early diagnosis is a good prognostic feature of childhood acute leukemia.
\end{abstract}

Keywords: Child; elbow; leukemia; septic arthritis.

Acute leukemia in children presents with various clinical manifestations that mimic orthopaedic conditions such as bone, joint, and musculoskeletal pain, creating difficulties in making the correct diagnosis..$^{[1-3]}$ Septic arthritis of the hip or knee joint has been described as one of the conditions related to acute leukemia. ${ }^{[1,2,4]}$ However, the association of septic arthritis of the elbow with acute leukemia is very rare, with only three cases previously reported
$\ddot{O} Z$

Çocuklarda akut lösemi ortopedik durumları taklit eden çeşitli klinik görünümlerle seyreder. Dirseğin septik artriti ile akut lösemi ilişkisi çok nadirdir ve doğru akut lösemi tanısı genellikle septik artritin tedavisinden sonra konulur. $\mathrm{Bu}$ yazıda, yüksek şüphe indeksinin devamı nedeniyle septik dirseğin acil cerrahi debridmanı olarak aynı gün kemik iliği aspirasyonu ile hemen tanı konulup mümkün olan en kısa zamanda kemoterapi ile tedavi edilen akut lösemi ile ilişkili dirsek septik artriti olan üç yaşında bir çocuk hasta sunuldu. Acil servis hekimi ve ortopedist bunun gibi olağandışı sunum örüntülerini fark etmelidir. Septik artrit tedavisinin başlatılmasında gecikme büyüme bozukluğuna yol açabildiğinden, çocukluk çağı akut lösemisi ile ilişkili dirsek septik artriti hızla ve uygun şekilde tedavi edilmelidir. Erken tanı çocukluk çağı akut lösemisinin iyi bir prognostik niteliğidir.

Anahtar sözcükler: Çocuk; dirsek; lösemi; septik artrit.

in the English literature. ${ }^{[5-7]}$ In those cases, the correct diagnosis of acute leukemia occurred only after treatment of the septic arthritis. To our knowledge, this is the first case report of acute leukemia diagnosed promptly by bone marrow aspiration on the same day as emergency surgical debridement of the septic elbow joint, and treated with chemotherapy as soon as possible, providing successful outcomes for septic arthritis and leukemia.

- Received: July 14, 2015 Accepted: August 15, 2015

- Correspondence: Takuya Uemura, MD. PhD. Department of Orthopaedic Surgery, Osaka City University Graduate School of Medicine, 1-4-3 Asahimachi Abeno-ku, Osaka 545-8585, Japan. Tel: +81-6-6645-3851 Fax: +81-6-6646-6260 e-mail: †-uemura@med.osaka-cu.ac.jp 


\section{CASE REPORT}

A three-year-old male patient was admitted to the pediatric hospital because of constant high fever with cold symptoms for more than two weeks. As his fever persisted in spite of administration of antibiotics, and anemia and thrombocytopenia progressed without related histories, he was transferred to our university hospital. At the first medical examination, patient's right elbow had redness, pain and swelling with some scratches on the cubital fossa, and the body temperature remained 38 degrees (Figure 1). A blood sample examination showed that the total leukocyte count was $4,100 / \mu \mathrm{L}$, in which neutrophils were decreased to $29.2 \%$ and lymphocytes were increased to $68.8 \%$ with a small number of erythroblasts. Erythrocyte count was 3,700,000/ $\mu \mathrm{L}$, and the value of hemoglobin was $10.8 \mathrm{~g} / \mathrm{dL}$. The thrombocyte count was decreased to $50,000 / \mu \mathrm{L}$. C-reactive protein levels and sedimentation rate were increased to $7.93 \mathrm{mg} / \mathrm{dL}$ and $55 \mathrm{~mm} / \mathrm{h}$, respectively. An X-ray of the patient's right elbow showed no irregularities of the epiphyseal lines and articular surfaces (Figure 2a). The magnetic resonance image showed significant joint effusion in the elbow but no effusion in the hip and knee joint (Figure 2b).

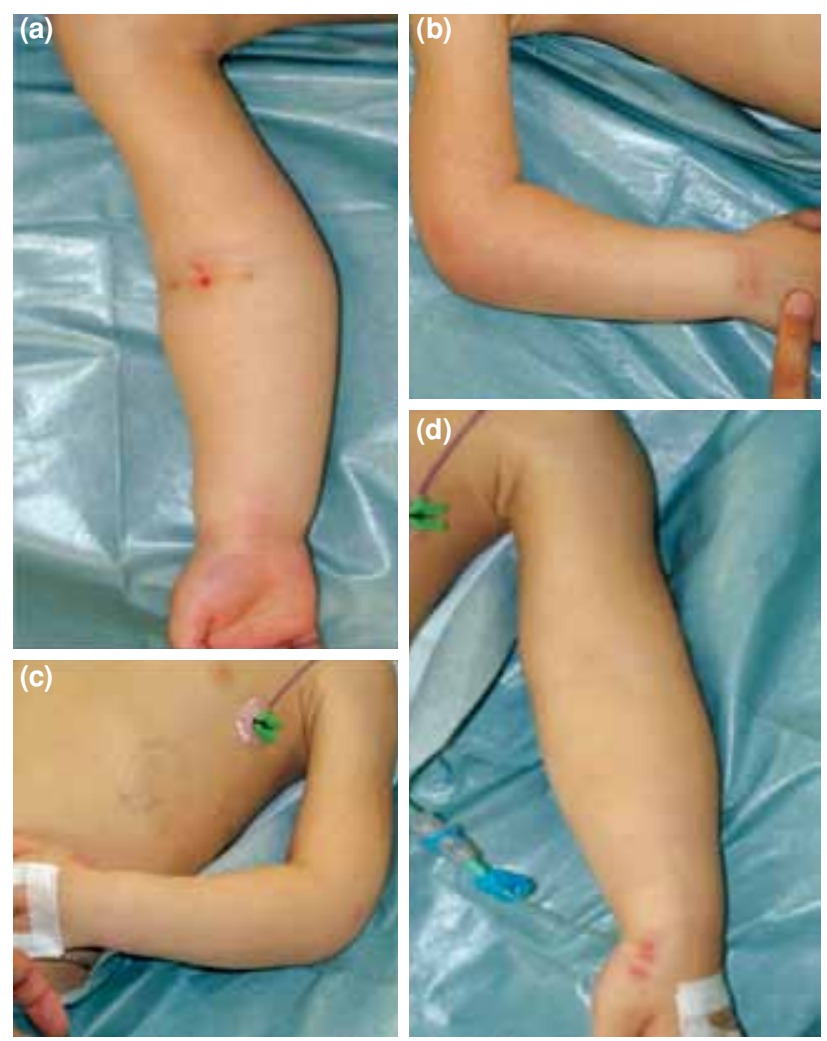

Figure 1. Preoperative appearance of elbow joint on right (a, b) and left (c, d) sides. Right elbow had swelling and redness with some scratches on cubital fossa. (a, b).
Based on these findings, the patient was diagnosed with septic elbow arthritis due to suspected neoplastic disease like acute leukemia. On the day of transfer, both emergency surgical arthrotomy of the elbow and sternum bone marrow aspiration for prompt diagnosis of leukemia were performed under general anesthesia. During surgery, reddish-brown joint effusion was discharged through mini lateral incision (Figure 2c), and the joint was irrigated with sufficient saline. After surgery, closed-suction drainage systems were applied for eight days, and the elbow was immobilized in a long arm cast for 12 days. Antibiotics (minocycline, meropenem, and micafungin) were continued postoperatively, with vancomycin replacing the minocycline two weeks after surgery. Eventually, the postoperative administration of antibiotics was continued for a total of three weeks, although the blood cultures and joint fluid culture were both negative. The diagnosis of acute lymphoblastic leukemia was confirmed three days after surgery, and early chemotherapy of steroid pulse in combination with intrathecal methotrexate was initiated at just 10 days after surgery; this was conducted carefully so as not to worsen the elbow infection. At 17 days after surgery, the C-reactive protein level became negative. At 15 months after surgery, the elbow joint pain and swelling disappeared and full range of motion returned (Figure 2d). Subsequent $\mathrm{X}$-rays showed neither joint nor epiphyseal damage (Figure 2e). The patient was able to use his elbow without limitation and continue chemotherapy for acute lymphoblastic leukemia without recrudescence.

\section{DISCUSSION}

Leukemia is the most common cancer type in children, ${ }^{[2]}$ and acute leukemia can mimic a wide range of orthopaedic pathologies such as bone, musculoskeletal, and joint pain at presentation. This may cause difficulty in establishing a diagnosis because patients may seek orthopedic or emergency treatment initially..$^{[1,2,4]}$ Teo et al. ${ }^{[8]}$ also reported that the diagnosis of childhood hematological malignancy with first bony presentation to the emergency room was challenging, with a high rate of undiagnosed cases (71.4\% at first visit). Failure to diagnose hematological malignancy correctly may delay timely institution of treatment.

The metaphyseal lucent band (the so-called classic leukemia line originally described by Baty and Vogt) has been widely known for a long time regarding the radiographic abnormalities associated with leukemia in children, with an incidence of 44 to $70 \%$ reported in children with leukemia. ${ }^{[2,3]}$ Musculoskeletal complaints, typically bone pain, were the presenting 

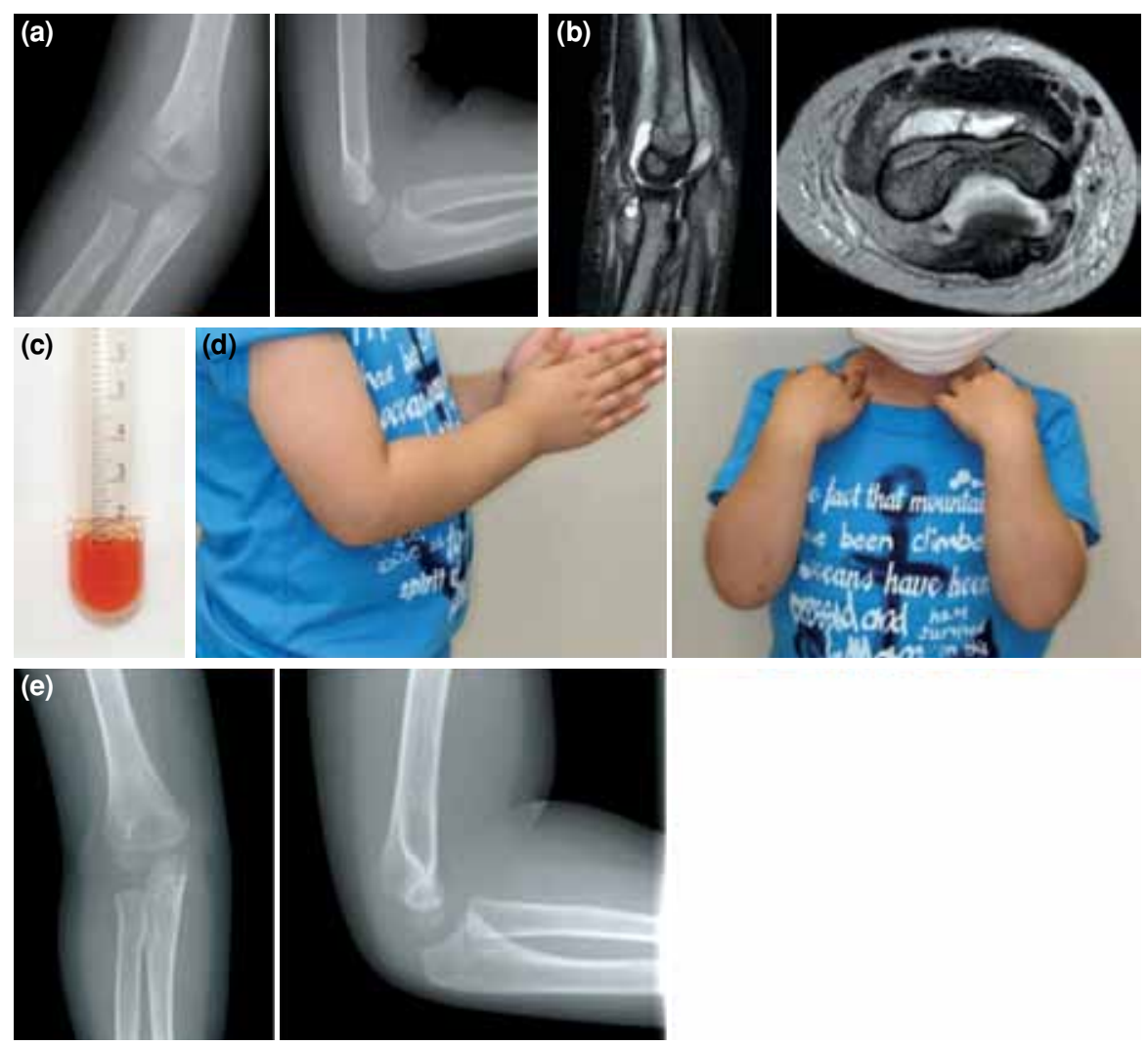

Figure 2. (a) Preoperative anteroposterior and lateral radiographs of elbow. (b) Preoperative magnetic resonance imaging of elbow. Fluid was observed in elbow joint in both coronal and axial $\mathrm{T}_{2}$ weighted images. (c) Appearance of joint fluid discharged through mini open arthrotomy. (d) Appearance of elbow joint at 15 months after surgery.

(e) Anteroposterior and lateral radiographs of elbow at 15 months after surgery.

symptoms in children with leukemia, with a reported incidence between 14 to $33 \% \%^{[2,3]}$ This is caused by massive proliferation of hematopoietic tissue within medullary cavities, most commonly in long bones and vertebral bodies. ${ }^{[2]}$ However, septic arthritis associated with leukemia in children is often atypical. In 107 children with acute leukemia, Rogalsky et al. ${ }^{[2]}$ reported that only four $(3.7 \%)$ had symptoms of septic arthritis (three of the hip and one of the knee). Riccio et al ${ }^{[1]}$ reported on the musculoskeletal manifestations in 328 children with acute leukemia, of whom only seven $(2.1 \%)$ had symptoms of septic arthritis but whose locations were not documented. Chell et al. ${ }^{[4]}$ reported on 24 new cases of acute pediatric leukemia, of whom three (12.5\%) had possible septic arthritis (one of the hip, one of the knee, and one of the ankle). Thus, septic arthritis related to acute leukemia is rare and located almost always in the joints of the lower extremities, most often in the hip and knee, and very rarely in the elbow. To our knowledge, the literature on elbow septic arthritis in relation to pediatric acute leukemia is limited to only three case reports. ${ }^{[5]}$ Robinson $^{[5]}$ reported on a 13-year-old girl who had a painful, swollen left elbow and was treated with arthrotomy of that elbow; she eventually was diagnosed with acute lymphoblastic leukemia by bone marrow aspiration a week after the procedure. Yang et al. ${ }^{[6]}$ reported on a three-year-old girl who presented with Salmonella arthritis involving multiple joints (shoulder, elbow and proximal interphalangeal joint of the index finger), which was diagnosed by blood culture without joint fluid culture. No arthrotomy was performed, and the diagnosis of acute lymphoblastic leukemia was confirmed two weeks later. Cimaz et al. ${ }^{[7]}$ reported four cases of childhood elbow arthritis due to leukemia, including a case suspected of septic elbow arthritis. No arthrotomy was performed, and the diagnosis of acute lymphocytic leukemia was confirmed three weeks later. The present case showed septic monoarticular arthritis of the elbow treated with surgical arthrotomy and debridement, providing prompt diagnosis by the bone marrow aspiration on that very day of surgery and starting the earliest possible chemotherapy for acute leukemia. 
The prompt recognition and early correct diagnosis of acute leukemia may prove to be a good prognostic feature of childhood acute leukemia. ${ }^{[8]}$ This is also true for the acute leukemia in adults. ${ }^{[9]}$

Septic arthritis is a medical and surgical emergency that, if left untreated, may lead to permanent joint disfigurement and loss of function..$^{[10,11]}$ In general, septic arthritis often occurs in children younger than five years of age, with a male-to-female ratio of approximately 2:1. ${ }^{[10]}$ Most studies note that approximately $90 \%$ of arthritis is monoarticular and occurs mainly in the knee and hip, followed by the ankle. ${ }^{[10,12]}$ The joint fluid culture was negative in the present case, and this result occurs in 45 to $60 \%$ of septic arthritis cases even if cultures are obtained before antibiotics are administered..$^{[5,10,11]}$ Especially in acute leukemia, it remains unclear whether the bacterial infection is located in the joint or the inflammatory changes in the joint are caused by malignancy ${ }^{[5]}$ In the present case, the child had had constant high fever with pancytopenia, and the elbow joint was still painful, locally heated, and swollen with scratches. The culture of the elbow fluid was negative but its cytology was class II with increased leukocyte count. Considering all factors, we diagnosed septic arthritis of the elbow and had to perform both emergency surgical debridement and bone marrow aspiration for prompt diagnosis of acute leukemia, which allowed for the quick start of chemotherapy.

We have reported on a three-year-old child with elbow septic arthritis related to acute leukemia. The emergency physician and orthopedist must recognize unusual patterns of presentation like this that characterize leukemia. The correct diagnosis and appropriate treatment must be prompt, because delay in initiating treatment of septic arthritis results in joint destruction and growth disturbance. Early diagnosis is a good prognostic feature of childhood acute leukemia.

\section{Declaration of conflicting interests}

The authors declared no conflicts of interest with respect to the authorship and/or publication of this article.

\section{Funding}

The authors received no financial support for the research and/or authorship of this article.

\section{REFERENCES}

1. Riccio I, Marcarelli M, Del Regno N, Fusco C, Di Martino $\mathrm{M}$, Savarese R, et al. Musculoskeletal problems in pediatric acute leukemia. J Pediatr Orthop B 2013;22:264-9.

2. Rogalsky RJ, Black GB, Reed MH. Orthopaedic manifestations of leukemia in children. J Bone Joint Surg Am 1986;68:494-501.

3. Silverstein MN, Kelly PJ. Leukemia with osteoarticular symptoms and signs. Ann Intern Med 1963;59:637-45.

4. Chell J, Fernandes JA, Bell MJ. The orthopaedic presentation of acute leukaemia in childhood. Ann R Coll Surg Engl 2001;83:186-9.

5. Robinson JL. Leukemia presenting as purulent septic arthritis. Orthopedics 2001;24:281-2.

6. Yang WC, Huang YC, Tsai MH, Chiu CH, Jaing TH. Salmonella septic arthritis involving multiple joints in a girl with acute lymphoblastic leukemia at diagnosis. Pediatr Neonatol 2009;50:33-5.

7. Cimaz R, Lippi A, Falcini F. Elbow arthritis: a rare inaugural manifestation of acute leukemia. Rev Rhum Engl Ed 1999;66:520-2.

8. Teo WY, Chan MY, Ng KC, Tan AM. Bony presentations of childhood haematological malignancy to the emergency room. J Paediatr Child Health 2012;48:311-6.

9. Beytemür O, Tetikkurt ÜS, Albay C, Adanır O, Güleç MA. Acute myeloid leukemia diagnosed with soft tissue mass in the right thigh. [Article in Turkish] Eklem Hastalik Cerrahisi 2015;26:56-9.

10. Caksen H, Oztürk MK, Uzüm K, Yüksel S, Ustünbaş HB, Per H. Septic arthritis in childhood. Pediatr Int 2000;42:534-40.

11. Bowakim J, Marti R, Curto A. Elbow septic arthritis in children: clinical presentation and management. J Pediatr Orthop B 2010;19:281-4.

12. Fink CW, Nelson JD. Septic arthritis and osteomyelitis in children. Clin Rheum Dis 1986;12:423-35. 